\title{
Feasibility of using metals to remediate water containing TCE
}

\author{
Shu-fen Cheng *, Shian-chee Wu \\ Graduate Institute of Environmental Engineering, National Taiwan University, 71, Chou-Shan Road, Taipei, Taiwan, ROC
}

Received 7 March 2000; received in revised form 20 June 2000; accepted 22 June 2000

\begin{abstract}
The feasibility of treating underground water contaminated by a chlorinated organic compound with bimetallics Fe/ $\mathrm{Ni}, \mathrm{Zn} / \mathrm{Ni}$ and $\mathrm{Zn}$ single metal was studied. Column tests to simulate a reactive permeable wall in a funnel-and-gate system were used. Research results indicated that bimetallic $\mathrm{Fe}^{0} / \mathrm{Ni}^{0}$ and $\mathrm{Zn}^{0} / \mathrm{Ni}^{0}$ all had a very strong degraded power to trichloroethylene (TCE ) at concentration up to $25 \mathrm{mg} / 1$ under different flow rates $(27 \mathrm{~cm} /$ day- $20 \mathrm{~m} /$ day). Furthermore, the concentrations of TCE and various ions in the treated effluent were nearly lower than the values specified in related standards for drinking water in Taiwan. These results showed that this technique could be effectively and safely used as an underground water remediation process. (c) 2001 Elsevier Science Ltd. All rights reserved.
\end{abstract}

Keywords: Chlorinated organic compound; Bimetallic; Remediation; Funnel-and-gate

\section{Introduction}

Trichloroethylene (TCE) is commonly used in the industry, mainly for degreasing, production of resins and plastics, and extraction of organic compounds. The use of TCE in large quantities without proper disposal procedures can often cause soil and underground water contaminations. For example, RCA factory at Taoyuan, Taiwan, has caused serious soil and underground water contaminations in the factory site and the nearby ground due to improper treatment of chlorinated compounds, such as tetrachloroethylene and TCE.

Zero-valent iron in combination with a funnel-andgate system is a new finding in the underground water remediation technique (Smyth et al., 1995). Researches on this technique carried out by others (Gillham and O'Hannesin, 1994; Matheson and Tratnyek, 1994; Orth and Gillham, 1996; Weber, 1996; O'Hannesin and Gillham, 1998) have demonstrated that zero-valent iron indeed is effective in removing chlorinated organic

\footnotetext{
${ }^{*}$ Corresponding author. Fax: +886-2-2362-9435.

E-mail address: d4541004@ms.cc.ntu.edu.tw (S.-f. Cheng).
}

compounds. It has been shown that under natural conditions, the surface of zero-valent iron is liable to form an oxide film thereby reducing its reactivity, and consequently affecting its value in in-situ applications (Wang and Zhang, 1997).

The dechlorinated reaction of zero-valent iron to chlorinated organic compounds essentially involves two mechanisms (Vogel et al., 1987; Smyth et al., 1995): (1) the chlorinated compound is adsorbed on the surface of metal iron and directly generates an electron conversion, and (2) the zero-valent iron first reacts with water molecules in the reaction system

$\mathrm{Fe}^{0}+2 \mathrm{H}_{2} \mathrm{O} \rightarrow \mathrm{Fe}^{+2}+\mathrm{H}_{2}+2 \mathrm{OH}^{-}$

and generates hydrogen gas which, in the presence of a catalyst is able to dechlorinate the chlorinated organic compounds

$\mathrm{RCl}+\mathrm{H}_{2} \stackrel{\text { catalyst }}{\rightarrow} \mathrm{RH}+\mathrm{Cl}^{-}+\mathrm{H}^{+}$

Based on the above-mentioned two reaction mechanisms, the metal needs to have a high reducing power or a high hydrogen overvoltage from the electrochemical point of view. The term "hydrogen overvoltage" means a voltage 
below which hydrogen generated by a metal undergoing the reaction of Eq. (1) in an aqueous solution exists in an atomic state. Hydrogen in its atomic state is the source of the primary reducing power in such a reaction system. When the voltage exceeds the hydrogen overvoltage of a metal, hydrogen atoms will combine together hydrogen molecules that no longer possess the reducing power. Therefore, a metal with a higher hydrogen overvoltage will have more hydrogen existing in its atomic state thereby generating a stronger reducing power. $\mathrm{Zn}^{0}$ not only has a higher standard reduction potential $E_{0}=$ $-0.763 \mathrm{~V}$ (Selley, 1977), but also is a metal with a high hydrogen overvoltage $0.70 \mathrm{~V}$. Therefore, electrochemically $\mathrm{Zn}^{0}$ is a good substitution in reducing a chlorinated compound.

When hydrogen atoms form hydrogen molecules, the reducing power thereof requires the assistance of a catalyst. Nickel is a good catalyst in the hydrogenation reaction and can dissociate hydrogen molecules into hydrogen atoms adhering on the surface of nickel metal (Bond, 1987; Appleton, 1996). Furthermore, nickel also has a rather strong chemical adsorption property to many chlorinated hydrocarbons (Bond, 1987). From the catalyst theories, for a molecule to undergo a catalytic reaction on the surface of a solid, it first must be chemically adsorbed. The surface atom of metal nickel has an empty orbit and is capable of adsorbing a compound having an un-bonded electron pair through a strong chemical adsorption (Bond, 1987). Therefore, the use of nickel as a catalyst for the hydrogen-dechlorinated reaction of a chlorinated organic compound should be a good choice.

In the past, our research project used batch tests to compare the dechlorinated reactions of zero-valent iron and zinc to a chlorinated organic compound (Cheng and $\mathrm{Wu}, 1998,2000)$. The results demonstrated that zinc had a better reactivity than iron, and the reactivity of zinc would not deteriorate rapidly even under oxygenated conditions. Furthermore, our research project also used batch tests to compare the dechlorinated reactions of bimetallics formed by adding nickel to $\mathrm{Fe}^{0}$ and $\mathrm{Zn}^{0}$ on chlorinated compounds. The results indicate that the addition of nickel significantly accelerates the reaction.

This research mainly used columns packed with zero-valent metals to simulate the reactive permeable wall in a funnel-and-gate system. Experiments were carried out continuously by simulating the typical flow rates of underground water. The concentrations of TCE aqueous solutions represent those present in the RCA contaminated site. The objectives of this study were to investigate the TCE degradation by zero-valent zinc and bimetallic $\mathrm{Fe} / \mathrm{Ni}$ and $\mathrm{Zn} / \mathrm{Ni}$. It is hoped that the results from the research may offer an alternative remediation technique that could treat a contaminated site.

\section{Methods}

\subsection{Experimental apparatus}

This research used circular glass columns packed with reactive metals to simulate the reactive permeable wall in a funnel-and-gate system. The column had a length of $100 \mathrm{~cm}$, with an inside diameter of $2.2 \mathrm{~cm}$ (a cross-sectional area of about $3.8 \mathrm{~cm}^{2}$ ). The bottom end of the column was a water inlet. Sampling outlets were installed at locations 30,60 and $90 \mathrm{~cm}$ from the bottom. A TCE aqueous solution was stored in a 21 brown serum bottle. A vermicular metering motor was used to control the flow rates into the columns. After flowing through the reactive metals, the effluent was collected in collection bottles through a Teflon hose connected to the top end of the column.

\subsection{Packing material of columns}

This research simultaneously used three columns, each packed with different metal materials. The first column was packed with a mixture of $\mathrm{Zn}^{0}$ and $\mathrm{Ni}^{0}$ with a weight ratio of 5:1, i.e., $1000 \mathrm{~g}$ of $\mathrm{Zn}^{0}$ and $200 \mathrm{~g}$ of Ni . $\mathrm{Zn}^{0}$ (Aldrich) was in the form of granules $(10+50$ mesh) with a purity of $99.8 \% . \mathrm{Ni}^{0}$ (Aldrich) was a powder (100 mesh) with a purity of $99.99 \%$. The average column porosity was 0.55 . The second column was packed with a mixture material of $\mathrm{Fe}^{0}$ and $\mathrm{Ni}^{0}$, also with a packing ratio of 5:1; wherein $\mathrm{Fe}^{0}$ (Acros) was a powder (325 mesh) with a purity of $99 \%$. The average column porosity was 0.42 . The third column was packed with a single metal $\mathrm{Zn}^{0}$ (Acros) in the form of granules, 30 mesh, P.A. grade, with a purity of $99.7 \%$. The average column porosity was 0.53 .

\subsection{Preparation of TCE aqueous solutions}

TCE was obtained from Merck (99.5\%). The TCE stock solution was prepared by dissolving $1 \mathrm{~g}$ of TCE solvent in $100 \mathrm{ml}$ of methanol (Methanol, Acros, $99.8 \%$ ). TCE aqueous solutions were prepared by diluting the stock solution with Milli-Q reagent water. The Milli-Q reagent water was pre-sparged with argon gas to remove dissolved oxygen.

\subsection{Column operator}

The concentrations of the TCE aqueous solution (2.5-25 $\mathrm{mg} / \mathrm{l})$ follow the actual pollution concentration range at the RCA contaminated site (Kueper, 1998). Due to the rather large flow rate differentials in the underground water, the flow rate of the aqueous solutions flowing through the column was gradually increased from $27 \mathrm{~cm} /$ day to a maximum of about $20 \mathrm{~m} /$ day by using a vermicular metering motor. 


\subsection{Sampling}

During the experiment, a $10 \mathrm{ml}$ syringe was used to periodically withdraw $5 \mathrm{ml}$ of aqueous sample from the sampling ports and the sample was immediately injected into a $15 \mathrm{ml}$ brown serum vial, and sealed with an aluminum crimp cap with a Teflon faced septum. The vials were placed in a thermostat at $25^{\circ} \mathrm{C}$ for over $1 \mathrm{~h}$ to let the compounds reach the equilibrium between the headspace and the aqueous phase. Furthermore, samples were also taken from the effluent to analyze the $\mathrm{pH}$ and the concentrations of chloride ions and metal ions of $\mathrm{Fe}^{0}, \mathrm{Zn}^{0}$ and $\mathrm{Ni}^{0}$.

\subsection{Analysis}

The concentrations of TCE were determined by using the gas chromatography headspace equilibration method. For each sample, $5 \mu$ of the headspace gas was taken by using a glass gas syringe, and then injected into the GC instrument.

Analyses for TCE were conducted using a 5890II Hewlett-Packard gas chromatography equipped with a $30 \mathrm{~m} \times 0.53 \mathrm{~mm}$ (I.D.) $\times 3.0 \mu \mathrm{m}$ (thickness), DB-624 capillary column $(\mathrm{J} \& \mathrm{~W})$ and an electron capture detector. The temperature was set as follows: oven temperature: $50^{\circ} \mathrm{C}$, injection port temperature: $220^{\circ} \mathrm{C}$, detector temperature: $250^{\circ} \mathrm{C}$. Nitrogen was used as the carrier gas at a flow rate of about $4.5 \mathrm{ml} / \mathrm{min}$. The method detection limit (MDL) for TCE was $0.2 \mu \mathrm{g} / \mathrm{l}$.

The chloride ions were analyzed by ion chromatography (Dionex). The packing column was IonPac ASII (4 mm, 10-32) with the MDL of $30 \mu \mathrm{g} / \mathrm{l}$. The ion concentrations of nickel, zinc and iron in the effluent were analyzed in an atomic absorption spectrophotometer (Perkin-Elmer 5000) of which the detection limits of zinc, nickel and iron were $0.02,0.15$ and $0.02 \mathrm{mg} / \mathrm{l}$, respectively. The $\mathrm{pH}$ value was measured by an electrode method (Orion, EA 920).

\section{Results and discussions}

\subsection{TCE degradation by bimetallic $\mathrm{Fe} / \mathrm{Ni}$ and $\mathrm{Zn} / \mathrm{Ni}$}

Before column tests, batch tests had been performed in serum vials for TCE degradation by using single metals $\mathrm{Fe}^{0}, \mathrm{Zn}^{0}$ and bimetallic $\mathrm{Zn}^{0} / \mathrm{Ni}^{0}$ and $\mathrm{Fe}^{0} / \mathrm{Ni}^{0}$. Results are shown in Fig. 1. Glass columns packed with bimetallic formed by homogeneously mixing $\mathrm{Fe}^{0}$ with $\mathrm{Ni}^{0}$, and $\mathrm{Zn}^{0}$ with $\mathrm{Ni}^{0}$ were used to simulate the reactive permeable wall in the funnel-and-gate system. Results indicated that bimetallics $\mathrm{Zn}^{0} / \mathrm{Ni}^{0}$ and $\mathrm{Fe}^{0} / \mathrm{Ni}^{0}$ had a very good TCE degradation. In fact, the column packed with $\mathrm{Zn}^{0} / \mathrm{Ni}^{0}$ exhibited a nearly complete TCE degradation immediately after the column study. The con-

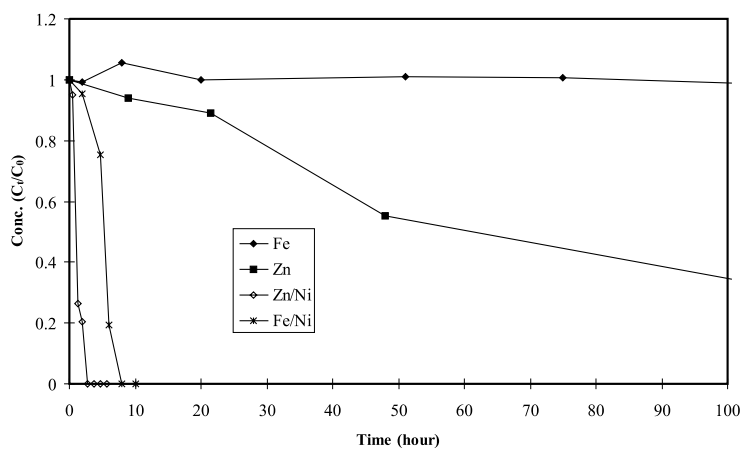

Fig. 1. TCE degradation by using single metal: $\mathrm{Fe}^{0}(3 \mathrm{~g}), \mathrm{Zn}^{0}(3$ g) and bimetallic: $\mathrm{Zn}^{0} / \mathrm{Ni}^{0}(3 \mathrm{~g} / 3 \mathrm{~g}), \mathrm{Fe}^{0} / \mathrm{Ni}^{0}(3 \mathrm{~g} / 3 \mathrm{~g})$. Conditions: Batch tests were performed in serum vials $(15 \mathrm{ml})$ in contact with $3 \mathrm{mg} / 1 \mathrm{TCE}$ at $25^{\circ} \mathrm{C}, 130 \mathrm{rpm}$.

centration of the TCE aqueous solution was increased gradually from 2.5 to $12.5 \mathrm{mg} / \mathrm{l}$ and the flow rate from 27 $\mathrm{cm} /$ day to $20 \mathrm{~m} /$ day. The concentrations of TCE measured at the first sampling port of the column $(30 \mathrm{~cm}$ from the inlet) were all below the $\operatorname{MDL}(0.2 \mu \mathrm{g} / 1)$. A trace amount of TCE (about $2.5 \mu \mathrm{g} / \mathrm{l}$ ) was detected at the first sampling port only when the concentration of the aqueous sample was increased to $25 \mathrm{mg} / \mathrm{l}$ and the flow rate at $20 \mathrm{~m} /$ day. The TCE concentrations of the aqueous samples taken at the second sampling port $(60 \mathrm{~cm}$ from the inlet opening) were below the detection limit.

For a column packed with $\mathrm{Fe}^{0} / \mathrm{Ni}^{0}$, the effluent still had a low concentration of TCE after the start up. Under conditions where the TCE concentration of the inlet water was $2.5 \mathrm{mg} / \mathrm{l}$ and the flow rate was $125 \mathrm{~cm} /$ day, the concentration of TCE measured at the first port was $48 \mu \mathrm{g} / 110 \mathrm{~h}$ later, $38 \mu \mathrm{g} / 1$ after $18 \mathrm{~h}, 2.5 \mu \mathrm{g} / \mathrm{l}$ after 34 $\mathrm{h}$, and below the detection limit after $58 \mathrm{~h}$. Thereafter, the concentrations of TCE measured at each sampling port were nearly all below the detection limit when the TCE concentration of inlet water varied from 2.5 to 25 $\mathrm{mg} / \mathrm{l}$ and the flow rate of the inlet water from $27 \mathrm{~cm} /$ day to $20 \mathrm{~m} /$ day. These results seemed to be similar to those of batch experiments done previously (Fig. 1). The batch experiments showed that the bimetallic $\mathrm{Fe}^{0} / \mathrm{Ni}^{0}$ had a slow degradation reaction to TCE at the initial stage of the reaction. However, TCE can be rapidly degraded after a slow reaction period of about $3 \mathrm{~h}$.

The column experiments of $\mathrm{Zn}^{0} / \mathrm{Ni}^{0}$ and $\mathrm{Fe}^{0} / \mathrm{Ni}^{0}$ of the present research were carried out continuously for two months. The results showed that the degradation effects of the two columns packed with bimetallics after two months were still good. Under operating conditions where the concentration of TCE was $10 \mathrm{mg} / \mathrm{l}$ and the flow rate $3 \mathrm{~m} / \mathrm{day}$, the TCE concentrations of the aqueous samples taken at all sampling ports of the two columns were nearly all below the detection limit. Even though the results of one or two analyses showed the 
presence of a minute amount of TCE, the concentrations of TCE were all below $1.0 \mu \mathrm{g} / \mathrm{l}$, far below the $5 \mu \mathrm{g} / \mathrm{l}$ specified in the drinking water standards in Taiwan. The results of this research indicated that the use of bimetallics $\mathrm{Zn} / \mathrm{Ni}$ or $\mathrm{Fe} / \mathrm{Ni}$ in treating underground water contaminated by chlorinated compounds, such as TCE, was a reliable method.

\subsection{Degradation of TCE by single metal $\left(\mathrm{Zn}^{0}\right)$}

Under same operating conditions as bimetallic (the concentration of TCE aqueous sample varied from 2.5 to $25 \mathrm{mg} / \mathrm{l}$, the water flow rate varied from $27 \mathrm{~cm} /$ day to $20 \mathrm{~m} /$ day, and the average reaction temperature was around $25^{\circ} \mathrm{C}$ ), this research also studied the effects of using single metal $\mathrm{Zn}^{0}$ to treat the TCE aqueous solution. The results showed that the degradation reaction of TCE was carried out in a first-order decay model. For example, Fig. 2 shows the results at the initial concentration of $10 \mathrm{mg} / 1 \mathrm{TCE}$ and the flow rate $96 \mathrm{~cm} / \mathrm{day}$. The first-order degradation rate constant was about $0.23 \mathrm{~h}^{-1}$ and the half-life was about $3 \mathrm{~h}$. Based on this degradation rate, if the TCE aqueous solution concentration of the underground water at a contaminated site was 25 $\mathrm{mg} / \mathrm{l}$, the retention time of the aqueous solution in the reactive $\mathrm{Zn}^{0}$ metal wall shall be designed to exceed $37 \mathrm{~h}$ in order for the concentration of the treated effluent to meet the regulation of $5 \mu \mathrm{g} / \mathrm{l}$ specified in the drinking water standard.

\subsection{Variation of effluent quality}

\subsubsection{Variation of $p H$}

The increasing of the $\mathrm{pH}$ would make the carbonic acid and bicarbonate that are present in groundwater produce the following reactions:

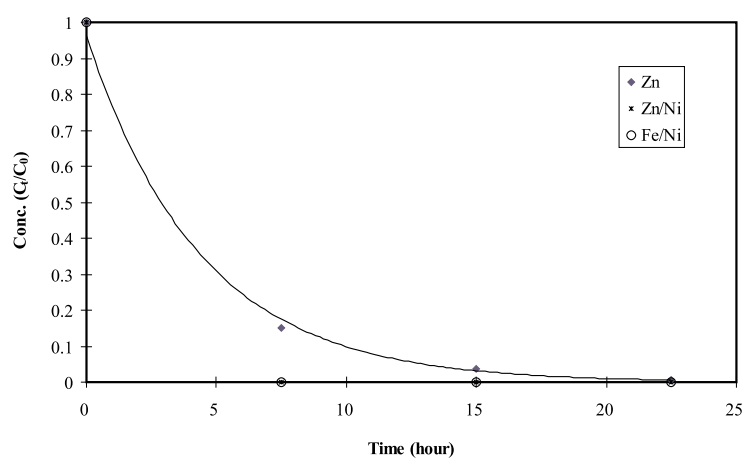

Fig. 2. TCE degradation by using single metal $\mathrm{Zn}^{0}$ and bimetallic $\mathrm{Zn}^{0} / \mathrm{Ni}^{0}$ and $\mathrm{Fe}^{0} / \mathrm{Ni}^{0}$. Column conditions: The initial concentration of TCE aqueous solution was $10 \mathrm{mg} / \mathrm{l}$, and the flow rate was $96 \mathrm{~cm} /$ day. The fit equation for TCE degradation by $\mathrm{Zn}$ was: $C_{t} / C_{0}=0.96 \mathrm{e}^{-0.23 t}\left(R^{2}=0.996\right)$.

$$
\begin{aligned}
& \mathrm{H}_{2} \mathrm{CO}_{3}+2 \mathrm{OH}^{-} \rightarrow \mathrm{CO}_{3}^{-2}+2 \mathrm{H}_{2} \mathrm{O} \\
& \mathrm{HCO}_{3}^{-}+\mathrm{OH}^{-} \rightarrow \mathrm{CO}_{3}^{-2}+2 \mathrm{H}_{2} \mathrm{O}
\end{aligned}
$$

The formation of carbonate ions would react with ions, such as $\mathrm{Ca}^{+2}, \mathrm{Mg}^{+2}$ and $\mathrm{Fe}^{+2}$ that are present in groundwater to form the precipitates. It would deposit on the surface of the zero-valent metals, potentially reduce the reactivity of the metals and decrease the porosity and hydraulic conductivity of the permeable wall. Therefore, the variation of the $\mathrm{pH}$ value in the system would be an important factor.

The effluent at the top of the column was also sampled to observe the $\mathrm{pH}$ variation of the effluent flowing through the reactive metal. The data in Fig. 3 show the $\mathrm{pH}$ variation with time for the feed and effluent of the three columns. Results showed that the $\mathrm{pH}$ of the effluent flown through a bimetallic $\mathrm{Fe} / \mathrm{Ni}$ column had a conspicuous increase. The value of $\mathrm{pH}$ of the inlet solution was nearly all within 6.5 and 7.1 . While the effluent $\mathrm{pH}$ values through bimetallic $\mathrm{Zn} / \mathrm{Ni}$ and $\mathrm{Zn}$ single metal were within 7.0 and 7.5 , respectively. The increase of $\mathrm{pH}$ was less than one unit and the $\mathrm{pH}$ had no obvious change during the experiment. Furthermore, there was no conspicuous relationship between the variation of $\mathrm{pH}$ and the concentration of TCE in the inlet aqueous. The effluent $\mathrm{pH}$ value through a column packed with bimetallic $\mathrm{Fe} / \mathrm{Ni}$ varied up to $\mathrm{pH}$ unit of 4 . During the initial stage of the experiment, the effluent $\mathrm{pH}$ value could be more than $11(\mathrm{pH}=11.4)$, and gradually decreased with the progress of the experiment. The $\mathrm{pH}$ value was below 11 after about half a month into the experiment, and dropped below 10 after 25 days. Based on the solubility product of $\mathrm{Zn}(\mathrm{OH})_{2}$ and $\mathrm{Fe}(\mathrm{OH})_{2}$ (Moeller and O'Connor 1972), when the independent system of $\mathrm{Zn}^{0}-\mathrm{H}_{2} \mathrm{O}$ and $\mathrm{Fe}^{0}-\mathrm{H}_{2} \mathrm{O}$ reaches a state of equilibrium, the $\mathrm{pH}$ value of the $\mathrm{Fe}^{0}-\mathrm{H}_{2} \mathrm{O}$ system is about $9.4(\mathrm{Ksp}$, $\left.\mathrm{Fe}(\mathrm{OH})_{2}=5 \times 10^{-15}\right)$ and the $\mathrm{pH}$ value of the $\mathrm{Zn}^{0}-\mathrm{H}_{2} \mathrm{O}$ system is about 8.6. For a long period, the effluent $\mathrm{pH}$ value in the $\mathrm{Fe} / \mathrm{Ni}$ column nearly reached the

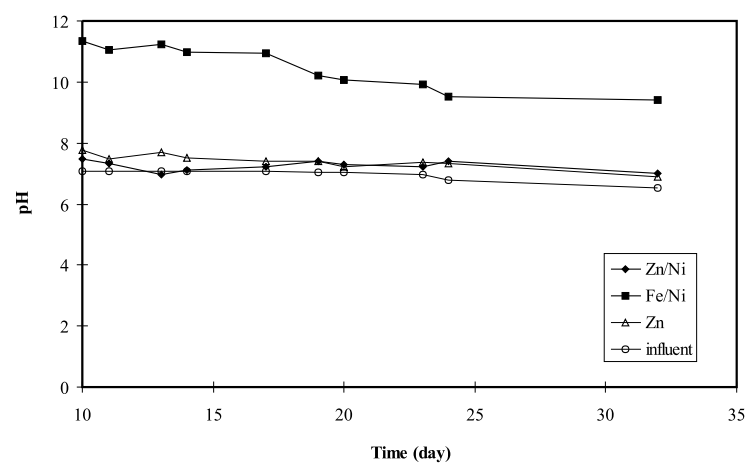

Fig. 3. The variation of the $\mathrm{pH}$ values for the inflow TCE aqueous solutions and the treated effluents. 
Table 1

The formation constants of various chloride and hydroxide complexes of $\mathrm{Zn}^{+2}, \mathrm{Fe}^{+2}$, and $\mathrm{Fe}^{+3}$ (Dean, 1973)

\begin{tabular}{lllll}
\hline & $K_{1}$ & $K_{2}$ & $K_{3}$ & $K_{4}$ \\
\hline Chloride & & & & \\
Iron (II) & $10^{0.36}$ & - & - & - \\
Iron (III) & $10^{1.48}$ & $10^{2.13}$ & $10^{1.99}$ & $10^{0.01}$ \\
Zinc & $10^{0.43}$ & $10^{0.61}$ & $10^{0.53}$ & $10^{0.20}$ \\
Hydroxide & & & & \\
Iron (II) & $10^{5.56}$ & $10^{9.77}$ & $10^{9.67}$ & $10^{8.58}$ \\
Iron (III) & $10^{11.87}$ & $10^{21.17}$ & $10^{29.67}$ & - \\
Zinc & $10^{14.3}$ & $10^{28.3}$ & $10^{41.9}$ & $10^{55.3}$ \\
Nickel & $10^{4.97}$ & $10^{8.55}$ & $10^{11.33}$ & - \\
\hline
\end{tabular}

equilibrium status. Another reason for the decrease of the $\mathrm{pH}$ value was that, after a long period of time, a portion of $\mathrm{Fe}$ had been oxidized into $\mathrm{Fe}^{+3}$, forming $\mathrm{Fe}(\mathrm{OH})_{3} \downarrow$ precipitation or other hydroxide ions of $\mathrm{Fe}^{+3}$ (refer to the formation constants in Table 1). As for the results of the effluents from the $\mathrm{Zn}$ and $\mathrm{Zn} / \mathrm{Ni}$ columns, the variation of the $\mathrm{pH}$ values are all near the neutral range. Since $\mathrm{Zn}(\mathrm{OH})_{2}$ is a amphoteric compound, it provides great buffer capacity for $\mathrm{OH}^{-}$.

\subsubsection{Dissolution of metal ions in the effluent}

An atomic absorption spectrophotometer was used to measure the concentration of $\mathrm{Fe}, \mathrm{Zn}$ and $\mathrm{Ni}$ ions in the effluent at the top end of each column in order to evaluate the metal content of the treated water for drinking water source. The analysis results showed that the concentrations of $\mathrm{Ni}$ ions in the effluent of the $\mathrm{Fe}^{0}$ / $\mathrm{Ni}^{0}$ and $\mathrm{Zn}^{0} / \mathrm{Ni}^{0}$ columns were all below the detection limit. Here, $\mathrm{Ni}^{0}$ plays a catalyst role and is not considered a main reactant. Therefore, there should have been no dissolution.

In a pure water reduction system, $\mathrm{Fe}^{0}$ is essentially dissolved in water in three forms of $\mathrm{Fe}^{+2}, \mathrm{Fe}(\mathrm{OH})^{+}$and $\mathrm{Fe}(\mathrm{OH})_{3}^{-}$(Benefield et al., 1982). Through a theoretical calculation, the total solubility is about $0.16 \mathrm{mg} / \mathrm{l}$ at

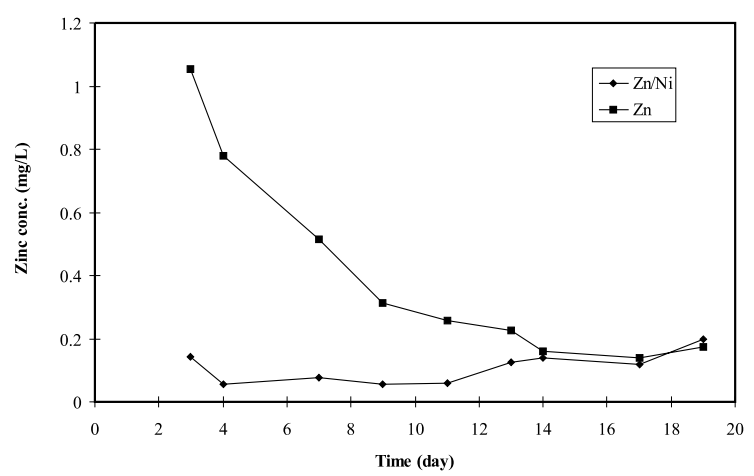

Fig. 4. The variations of the dissolution of zinc ions in the effluent from a column packed with bimetallic $\mathrm{Zn} / \mathrm{Ni}$ and a column packed with single metal $\mathrm{Zn}$.
$\mathrm{pH}=10$, and about $0.016 \mathrm{mg} / \mathrm{l}$ at $\mathrm{pH}=11$. Therefore, it was reasonable for the content of $\mathrm{Fe}$ ions to be below the detection limit in a complex reaction system. The results of experimental and theoretical calculations all demonstrate that the contents of heavy metal in the effluent treated by the bimetallics $\mathrm{Fe} / \mathrm{Ni}$ are all below the regulation of $0.3 \mathrm{mg} / \mathrm{l}$ specified for drinking water in Taiwan. The plots in Fig. 4 show the dissolution of $\mathrm{Zn}$ ions in the effluent from separate columns packed with bimetallics $\mathrm{Zn} / \mathrm{Ni}$ and with a single metal $\mathrm{Zn}^{0}$. The effluent through the single metal $\mathrm{Zn}$ column had a higher concentration of $\mathrm{Zn}$ ion. The concentration of $\mathrm{Zn}$ ions reached a maximum of $1060 \mu \mathrm{g} / \mathrm{l}$, decreased gradually along with the progress of the experiment, and finally stabilized at about $200 \mu \mathrm{g} / \mathrm{l}$. The concentration of $\mathrm{Zn}$ ions in the effluent from the bimetallic $\mathrm{Zn} / \mathrm{Ni}$ column was lower, generally below $200 \mu / 1$. Zinc is one of the elements essential to human body and has a higher standard of $5 \mathrm{mg} / \mathrm{l}$ for drinking water (Taiwan). The concentrations of $\mathrm{Zn}$ ions in the effluents of the present study were all far below the standard for drinking water. Therefore, if underground water were to be treated according to the technique of this research, the treated water as a drinking water source should not cause a human health hazard.

\subsubsection{Concentration of chloride ions in effluent}

Ion chromatography was used to measure the concentration of chloride ions in the effluent collected from the top end of the three columns. Results showed that the concentrations of chloride ions were higher in the effluent from the $\mathrm{Fe} / \mathrm{Ni}$ column, and those from $\mathrm{Zn} / \mathrm{Ni}$ and $\mathrm{Zn}$ columns were almost below the detection limit (Fig. 5), with a few detectable concentrations below 100 $\mu \mathrm{g} / \mathrm{l}$ (the standard of chloride for drinking water in Taiwan is $250 \mathrm{mg} / \mathrm{l}$ ). The variation of the concentration of chloride ions in the effluent from the bimetallics $\mathrm{Fe} / \mathrm{Ni}$ column did not have a special trend and ranged from the

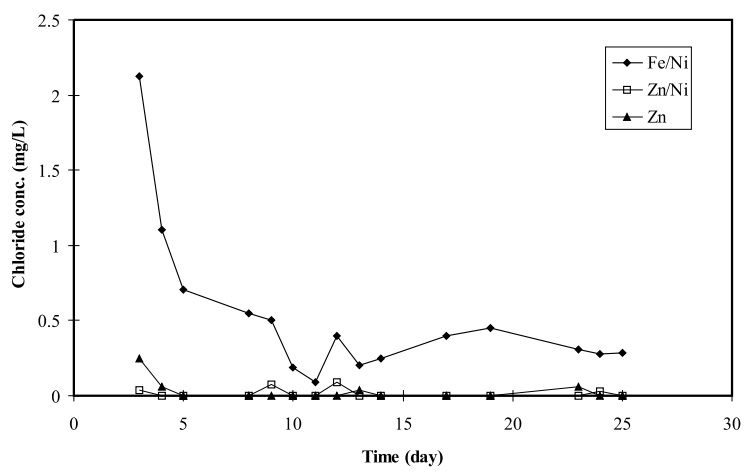

Fig. 5. The variations of the concentrations of chloride ions in the effluent from the bimetallic $\mathrm{Fe} / \mathrm{Ni}, \mathrm{Zn} / \mathrm{Ni}$ columns and single metal $\mathrm{Zn}$ column. 
initial maximum of about $2 \mathrm{mg} / \mathrm{l}$ to the minimum of about $70 \mu \mathrm{g} / \mathrm{l}$ (Fig. 5).

According to results mentioned above, the samples from the Fe/Ni column had lower concentration of $\mathrm{Fe}$ ions and higher concentration of chloride ions. Samples from the $\mathrm{Zn} / \mathrm{Ni}$ and $\mathrm{Zn}$ column had higher concentration of $\mathrm{Zn}$ ions and lower concentration of chloride ions. This phenomenon could be explained from the theory of complex metal formation. $\mathrm{Zn}^{+2}$ was easier to form a variety of complex compounds with $\mathrm{Cl}^{-}$than $\mathrm{Fe}^{+2}$, and the complex formation constant of $\mathrm{Zn}^{+2}$ is larger than that of $\mathrm{Fe}^{+2}$ (Table 1) and most of the chloride ions in the aqueous samples from the $\mathrm{Zn}$ contained column combined with $\mathrm{Zn}^{+2}$ to form a complex thereby causing a reduction in the concentration of chloride ions in the effluent. The formation of the metal complex also causes an increase in the solubility of the $\mathrm{Zn}$ ions, and subsequently an increase of the concentration in the effluent. The situation of $\mathrm{Fe}$ was opposite to that of $\mathrm{Zn}$.

\section{Conclusion}

Columns packed with bimetallics $\mathrm{Zn} / \mathrm{Ni}, \mathrm{Fe} / \mathrm{Ni}$ or single metal $\mathrm{Zn}$ were used to simulate the reactive permeable wall in the "funnel-and-gate system" for TCE removal. Results indicated that the concentration of TCE aqueous samples taken at the first sampling port of the bimetallic $\mathrm{Fe} / \mathrm{Ni}$ and $\mathrm{Zn} / \mathrm{Ni}$ columns were nearly all below $1.0 \mu \mathrm{g} / \mathrm{l}$; and the TCE concentrations of the aqueous samples taken at the second sampling port (i.e., $60 \mathrm{~cm}$ from the bottom inlet of the column) were all below the detection limit $(0.2 \mu \mathrm{g} / \mathrm{l})$, far below the standard of $5 \mu \mathrm{g} / \mathrm{l}$ for drinking water.

Regarding the aqueous quality of the effluent from the column, this research has demonstrated that the dissolution concentrations of $\mathrm{Fe}, \mathrm{Zn}$, and chloride ions are all far below the standards for drinking water; and the dissolution concentration of $\mathrm{Ni}$ ions is also below the detection limit of the instrument. Therefore, treated underground water can be used as drinking water source without causing a health hazard.

The use of bimetallics $\mathrm{Fe} / \mathrm{Ni}$ and $\mathrm{Zn} / \mathrm{Ni}$ as a packing material in the gate of the funnel-and-gate system for treating the underground water contaminated by chlorinated organic compounds not only is an efficient method, but also meets the standards of drinking water. This technique should be a feasible method in treating a contaminated site. Further studies of this technique should be carried out in order to understand how to effectively and economically apply this method to a remediation process of a contaminated site, or even to the treatment of industrial wastewater.

\section{Acknowledgements}

The authors gratefully acknowledge the financial support provided by the National Science Council, ROC, (Contract No. NSC 89-2621-Z-002-010) for this research work.

\section{References}

Appleton, E.L., 1996. A nickel-iron wall against contaminated groundwater. Environ. Sci. Technol. 30, 536-539.

Benefield, L.D., Judkins, J.F., Weand, B.L., 1982. Process Chemistry for Water and Wastewater Treatment. PrenticeHall, Englewood Cliffs, NJ.

Bond, G.C., 1987. Heterogeneous Catalysis: Principles and Applications. Clarendon Press, Oxford.

Cheng, S.F., Wu, S.C., 1998. Enhancing chlorinated methanes degradation by modifying the $\mathrm{Fe}^{0}$ reduction system. Physical, Chemical, and Thermal Technologies. Battelle Press, USA, C1-5, pp. 299-304.

Cheng, S.F., Wu, S.C., 2000. The enhancement methods for the degradation of TCE by zero-valent metals. Chemosphere 41, 1263-1270.

Dean, J.A., 1973. Lange's Handbook of Chemistry. McGrawHill, New York.

Gillham, R.W., O’Hannesin, S.F., 1994. Enhanced degradation of halogenated aliphatics by zero-valent iron. Ground Water 32, 958-967.

Kueper, B. and Associated, Ltd., 1998. Groundwater remediation technical practicability evaluation report - Taoyuan site, Taiwan, ROC, April.

Matheson, L.J., Tratnyek, P.G., 1994. Reduction dehalogenation of chlorinated methanes by iron metal. Environ. Sci. Technol. 28, 2045-2053.

Moeller, T., O'Connor, R., 1972. Ions in Aqueous Systems. McGraw-Hill, New York.

O'Hannesin, S.F., Gillham, R.W., 1998. Long-trem performance of an in situ "iron wall" for remediation of VOCs. Ground Water 36, 164-170.

Orth, W.S., Gillham, R.W., 1996. Dechlorination of trichloroethene in aqueous solution using $\mathrm{Fe}^{(0)}$. Environ. Sci. Technol. 30, 66-71.

Selley, N.J., 1977. Experimental Approach to Electrochemistry. Wiley, New York.

Smyth, D., Cherry, J., Jowett, R., 1995. Treat groundwater in place - in situ funnel-and-gate system corrals water for treatment. Soil and Groundwater Cleanup, 36-43.

Vogel, M.T., Criddle, C.S., McCarty, P.L., 1987. Transformations of halogenated aliphatic compounds. Environ. Sci. Technol. 21, 722-736.

Wang, C.B., Zhang, W.X., 1997. Synthesizing nanoscale iron particles for rapid and complete dechlorination of TCE and PCBs. Environ. Sci. Technol. 31, 2154-2156.

Weber, E.J., 1996. Iron-mediated reductive transformations: investigation of reaction mechanism. Environ. Sci. Technol. $30,716-719$. 